\title{
Beyond nature vs. nurture in expertise research - comment on Baker \& Wattie
}

\author{
David Z. Hambrick ${ }^{1, *}$ \& Alexander P. Burgoyne ${ }^{1}$ \\ 1 Department of Psychology, Michigan State University, East Lansing, Michigan, USA \\ * Corresponding author: Department of Psychology, Michigan State University, East Lansing, Ml 48824, United States, Tel: +01 517-303-1304 \\ E-Mail: hambric3@gmail.com
}

\section{COMMENTARY}

\section{Article History:}

Submitted $21^{\text {st }}$ February 2019

Accepted $6^{\text {th }}$ March 2019

Published $7^{\text {th }}$ May 2019

Handling Editor:

Lisa Steidl-Müller

University of Innsbruck, Austria

Editor-in-Chief:

Martin Kopp

University of Innsbruck, Austria

\section{ABSTRACT}

The field of expertise is mired in a nature vs. nurture debate. Despite what we now know from behavioral genetics research about the underpinnings of human behavior, some expertise theorists continue to deny or downplay the importance of genetic factors ("innate talent") in expert performance. In this commentary, we argue that this viewpoint is neither defensible nor productive. Our argument is based on two observations. First, there are always limits on human performance, even among individuals who have engaged in long periods of intensive training. Second, grounded in a neurobiological system that has evolved through natural selection, variation across people in phenotypes reflecting these limits will have a genetic component. We comment on directions for future research to advance the field of expertise.

Keywords:

Talent - expertise - individual differences - sports - training - natural selection

Citation:

Hambrick, D. Z. \& Burgoyne, A. P. (2019): Beyond nature vs. nurture in expertise research - comment on Baker \& Wattie Current Issues in Sport Science, 4:104. doi: 10.15203/CISS_2019.104

This is a commentary on a CISS report article authored by Baker, J. \& Wattie, N. (2018). Innate talent in sport: Separating myth from reality. Current Issues in Sport Science, 3:006. doi: 10.15203/CISS_2018.006

The scientific debate about whether innate talent plays a role in expert performance began more than a century and a half ago. Showing that eminent individuals tended to be biologically related, Sir Francis Galton (1869) argued in his book Hereditary Genius that greatness arises from "natural ability". The Swiss botanist Alphonse Pyrame de Candolle (1873), presenting his own data, countered that causes favorables-advantages such as wealth, education, and even a temperate climate-are the major factors in success. The debate has raged on ever since. It is a bit perplexing that we are still having this debate. Other fields long ago embraced the idea that nature and nurture, and their interplay, contribute to variation in human behavior. We are decades past any serious debate about whether traits such as intelligence, personality, and psychopathology are heritable (they are-substantially so). Nearly twenty years ago, the behavioral geneticist Eric Turkheimer (2000) wrote, "The nature- nurture debate is over. The bottom-line is that everything is heritable" (p. 160). Yet, here we are, having a debate about whether innate talent is a valid concept.

To be clear, no credible scientist believes that expert performance can be explained without recourse to nurture (i.e., the environment). This is because the type of specialized knowledge necessary for activities such as chess, music, and sports can only be acquired through some form of environmental exposure (i.e., training and other activities). We don't come into the world as "blank slates," but we certainly aren't born knowing the rules of chess, much less the Queen's Gambit.

Nevertheless, the view that expert performance can be explained without recourse to talent remains popular in both scientific and popular circles. John Watson (1924), the founder of behaviorism, famously guaranteed he could train any healthy infant to become "any type of specialist ...regardless of his 
talents" (p. 104). More recently, K. Anders Ericsson (2007) wrote, "it is possible to account for the development of elite performance among healthy children without recourse to unique talent (genetic endowment)" (p. 4). This view has been promoted in popular books on expertise, such as Talent is Overrated: What Really Separates World-Class Performers from Everybody Else (Colvin, 2010), The Talent Code: Greatness Isn't Born. It's Made. Here's How (Coyle, 2009), and Peak: Secrets from the New Science of Expertise (Ericsson \& Pool, 2016). The psychologist Scott Miller (2011) blogged, "What is widely believed however is not always true: flat earth, phrenology, cold fusion, and...innate talent."

The question of why the field of expertise remains mired in a nature vs. nurture debate while other fields have progressed is interesting to consider. Dogma dies hard, perhaps. However, this is a question for historians of science. Here, in this commentary on Joseph Baker and Nick Wattie's thoughtful target article, we offer our perspective on talent and thoughts on how to advance the field of expertise.

\section{The Inevitability of Heritability}

A decade before Galton published Hereditary Genius (1869), his half-cousin Charles Darwin published On the Origin of Species (1859). Darwin's revolutionary insight was that populations evolve through natural selection: the differential survival of members of a population based on differences in their characteristics. The upshot of natural selection is a discovery so robust that it has been dubbed the First Law of Behavioral Genetics (Turkheimer, 2000): if a behavioral characteristic (a phenotype) varies across people, there will be some contribution of genetic factors to that variation (Plomin, DeFries, Knopik, \& Neiderhiser, 2016; Sela \& Barbaro, 2018).

In view of this discovery, it would seem odd to argue that expert performance can be explained without recourse to genetic endowment-and it is odd. Through training, people can develop skills that enable them to circumvent normal limits on human performance (Ericsson, 2014; Ericsson \& Pool, 2016). This is not a controversial claim; this is the only sensible way to explain the feats of elite performers. Take "memory athletes" such as Lance Tschirhart, who holds the world record for memorizing random digits (at a bewildering 456; World-MemoryStatistics.com, 2016). Tschirhart is not holding 456 digits in his short-term memory; rather, through training, he has acquired skill in storing digits in long-term memory (see Ericsson, Chase, \& Faloon, 1980).

However, just because people can circumvent limits on performance does not mean that performance is without limits. There are always limits on human performance (and, for that matter, the performance of artificial systems such as Deep Blue). Circumvent one limit, and there will be others. Moreover, reflecting a neurobiological system that has evolved through natural selection, there will be heritable variation across people in phenotypes indexing those limits, whether they be cognitive phenotypes such as working memory, physical phenotypes such as height, neurological phenotypes such as white matter integrity, physiological phenotypes such as maximal oxygen uptake $\left(\mathrm{VO}_{2 \max }\right)$, or whatever. The level of these phenotypes will have an impact on a person's development in a domain (or lack thereof). Basketball and height is only the most obvious example: there have been only three players 5 -feet- 6 or shorter in NBA history ("24 Shortest NBA Players").

In short, there is no plausible reason to deny that talent impacts expert performance. All the same, it is important to ask what, exactly, talent is; otherwise, it might as well not exist because it can't be measured. Baker and Wattie (2019) provide a useful discussion. Along the lines just discussed, they argue that talent is a valid concept, because it must be: "An evolutionary probabilistic standpoint assumes there is a distribution of ability and/or individual characteristics (i.e., degrees of talent) across a population with very small numbers of individuals at the very highest and lowest levels" (Baker \& Wattie, 2019, p. 4). They add, however, that "with the exception of a few variables related to body size, no robust indicators of talent currently exist" (p. 7). We are surprised by this claim. Numerous twin studies have found moderate-to-large heritability estimates for sports-relevant physiological characteristics. For example, a recent meta-analysis found average heritability of $59 \%$ for $\mathrm{VO}_{2 \max }$ (Schutte, Nederend, Hudziak, Bartels, \& de Geus, 2016). $\mathrm{VO}_{2 \max }$ can be increased with training (see, e.g., Skinner et al., 2001), but so can many highly heritable phenotypes (e.g., muscle mass; Aagaard et al., 2004; Georgiades, Klissouras, Baulch, Wang, \& Pitsiladis, 2017). Heritability and modifiability are independent considerations.

\section{Intellectual Talent}

We further note that psychologists discovered a robust indicator of intellectual talent well over a century ago. Given a reasonably large and representative sample of subjects, scores on tests of different cognitive abilities will correlate positively with each other, implying the existence of a general factor of intelligence (Jensen, 1998). This " $g$ " factor is one of the most replicated findings in psychological science. Three things about $g$ are clear (see Ritchie, 2015). First, there is just one $g$. Correlations between estimates of $g$ extracted from different test batteries are near 1.0 (Johnson, Bouchard, Krueger, McGue, \& Gottesman, 2004). Second, $g$ is stable across time. A person high in $g$ in childhood will likely be so for the rest of their life (Deary, Whalley, Lemmon, Crawford, \& Starr, 2000). Finally, $g$ has practical utility. It predicts socially relevant outcomes such as academic achievement and job performance better than any other single variable (Schmidt \& Hunter, 2004).

There is relatively little evidence for the role of $g$ in developing sports expertise. Significant correlations between measures of cognitive ability and sports performance have sometimes been observed, but just as often not (see Hambrick, Burgoyne, \& Oswald, 2019, for a review). Nevertheless, we think that a con- 
sideration of the role of innate talent in sports expertise must include $g$. The question of why $g$ sometimes predicts sports performance, but other times not, is particularly interesting. It could be that $g$ predicts performance in individual sports but not group sports in which team-level factors may compensate for individual-level factors. Research aimed at answering this type of question will enrich our understanding both of $g$ as a form of intellectual talent, and of the underpinnings of sports expertise.

\section{Conclusion}

Research on the nature and nurture of complex skill will move the field of expertise ahead. The knowledge gained from this research will provide a scientific foundation for accelerating the acquisition of expert performance. For example, as is already being done in sports, it may one day be possible to tailor training in domains such as music based on performers' genotypes. Far from limiting people's potential, this type of intervention will bring expert performance within reach of more people than is currently the case.

\section{Funding}

The author(s)s has/have no funding or support to report.

\section{Competing Interests}

The author(s) has/have declared that no competing interests exist.

\section{Data Availability Statement}

All relevant data are within the paper.

\section{References}

24 shortest NBA players to ever take the course (February 14, 2018). Hero Sports. Retrieved from: https://herosports.com/ nba/shortest-nba-players-muggsy-bogues-earl-boykinskeith-jennings-spud-webb-aiai

Aagaard, P., Andersen, J. L., Dyhre-Poulsen, P., Leffers, A. M., Wagner, A., Magnusson, S. P., Halkjær-Kristensen, J., \& Simonsen, E. B. (2001). A mechanism for increased contractile strength of human pennate muscle in response to strength training: changes in muscle architecture. The Journal of Physiology, 534, 613-623.

Baker, J., \& Wattie, N. (2018). Innate talent in sport: Separating myth from reality. Current Issues in Sport Science (CISS), 3, 1-9.
Carmichael, C. M., \& McGue, M. (1995). A cross-sectional examination of height, weight, and body mass index in adult twins. Journals of Gerontology: Biological Sciences, 50A, B237-B244.

Colvin, G. (2010). Talent is overrated: What really separates worldclass performers from everybody else. New York City, NY: Penguin.

Coyle, D. (2009). The talent code: Greatness isn't born, it's grown. And here's how. New York City, NY: Random House.

Darwin, C. (1859). On the origin of species. Retrieved from https://www.gutenberg.org/files/2009/2009-h/2009-h.htm

de Candolle, A. P. (1873). Histoire des Sciences et des Savants Depuis Deux Siècles. Retrieved from http://biodiversitylibrary. org/page/27318242\#page/10/mode/1up

Deary, I. J., Whalley, L. J., Lemmon, H., Crawford, J. R., \& Starr, J. M. (2000). The stability of individual differences in mental ability from childhood to old age: follow-up of the 1932 Scottish Mental Survey. Intelligence, 28, 49-55.

Ericsson, K. A. (2007). Deliberate practice and the modifiability of body and mind: Toward a science of the structure and acquisition of expert and elite performance. International Journal of Sport Psychology, 38, 4-34.

Ericsson, K. A. (2014). Why expert performance is special and cannot be extrapolated from studies of performance in the general population: A response to criticisms. Intelligence, 45, 81-103.

Ericsson, A., \& Pool, R. (2016). Peak: Secrets from the new science of expertise. Boston, MA: Houghton Mifflin Harcourt.

Ericcson, K. A., Chase, W. G., \& Faloon, S. (1980). Acquisition of a memory skill. Science, 208(4448), 1181-1182.Ericsson, K. A., Krampe, R. T., \& Tesch-Römer, C. (1993). The role of deliberate practice in the acquisition of expert performance. Psychological Review, 100, 363-406.

Galton, F. (1869). Hereditary genius: An inquiry into its laws and consequences (Vol. 27). London, UK: Macmillan.

Georgiades, E., Klissouras, V., Baulch, J., Wang, G., \& Pitsiladis, Y. (2017). Why nature prevails over nurture in the making of the elite athlete. BMC Genomics, 18, 59-66.

Hambrick, D. Z., Burgoyne, A. P., \& Oswald, F. L. (2019). Domaingeneral models of expertise: The role of cognitive ability. In P. Ward, J. M. Schraagen, J. Gore, \& E. Roth (Eds.), The Oxford Handbook of Expertise. Oxford, UK: Oxford University Press.

Jensen, A. R. (1998). The $g$ factor: The science of mental ability (Vol. 648). Westport, CT: Praeger.

Johnson, W., Bouchard Jr, T. J., Krueger, R. F., McGue, M., \& Gottesman, I. I. (2004). Just one g: Consistent results from three test batteries. Intelligence, 32, 95-107.

Miller, S. (2011). Deliberate practice: What's all the fuss about. Archived: https://web.archive.org/save/https://www.scottdmiller.com/deliberate-practice-whats-all-the-fuss-about/

Plomin, R., DeFries, J. C., Knopik, V. S., \& Neiderhiser, J. M. (2016). Top 10 replicated findings from behavioral genetics. Perspectives on Psychological Science, 11, 3-23. 
Ritchie, S. (2015). Intelligence: All that matters. Hodder \& Stoughton.

Schmidt, F. L., \& Hunter, J. (2004). General mental ability in the world of work: occupational attainment and job performance. Journal of Personality and Social Psychology, 86, 162173.

Schutte, N. M., Nederend, I., Hudziak, J. J., Bartels, M., \& de Geus, E. J. C. (2016). Twin-sibling study and meta-analysis on the heritability of maximal oxygen consumption. Physiological Genomics, 48, 210-219.

Sela, Y. \& Barbaro, N. (2018). Evolutionary perspectives on personality and individual differences. In V. Zeigler-Hill \& T. K. Shackelford (Eds.), The SAGE handbook of personality and individual differences (pp. 203-228). London: Sage.

Skinner, J. S., Jaskólski, A., Jaskólska, A., Krasnoff, J., Gagnon, J., Leon, A. S., Rao, D. C., Wilmore, J. H., \& Bouchard, C. (2001). Age, sex, race, initial fitness, and response to training: the HERITAGE Family Study. Journal of Applied Physiology, 90, 1770-1776.

Turkheimer, E. (2000). Three laws of behavior genetics and what they mean. Current Directions in Psychological Science, 9, 160-164.

Watson, J. B. (1924). Behaviorism. New York: People's Institute. (Rev. Ed. 1930).

World-Memory-Statistics.com. (2016). Retrieved February 14, 2019, from http://www.world-memory-statistics.com/disciplines.php 